УДК 378:372.881.111.1

\title{
DEVELOPING MEDIATIVE COMPETENCE AS SOFT SKILLS COMPONENT OF FUTURE FOREIGN LANGUAGE TEACHERS
}

Piskurska Hanna, PhD in Pedagogy, Associate Professor, Associate Professor at Language Training Department, Donetsk National Technical University.

ORCID: 0000-0003-0957-8987

E-mail: ganna.piskurska@donntu.edu.ua

Popova Oksana, PhD in Pedagogy, Associate Professor at Language Training Department, Donetsk National Technical University.

ORCID: 0000-0001-9030-542X

E-mail: oksana.popova@donntu.edu.ua

The article focuses on the problem of developing soft skills of the students majoring in Foreign Language Teaching. The article aims at designing a set of exercises for developing the mediative competence as a component of future foreign language teachers' soft skills. The following groups of exercises have been selected and described: non-communicative analytical, receptive, partially analytical mediative, and purely communicative. It is concluded that the mediative competence of future foreign language teachers is acquired by the integration of all types of training exercises.

Keywords: professional competence; soft skills; mediative competence; meditative activity; professional training; foreign language teacher; student; exercise.

\section{РОЗВИТОК МЕДІАТИВНОЇ КОМПЕТЕНТНОСТІ ЯК СКЛАДОВОЇ SOFТ SКILLS МАЙБУТНІХ УЧИТЕЛІВ IHOЗЕМНОÏ МОВИ}

Піскурська Ганна, кандидат педагогічних наук, доцент, доцент кафедри мовної підготовки, Державний вищий навчальний заклад «Донецький національний технічний університет».

ORCID: 0000-0003-0957-8987

E-mail: ganna.piskurska@donntu.edu.ua

Попова Оксана, кандидат педагогічних наук, доцент кафедри мовної підготовки, Державний вищий навчальний заклад «Донецький національний технічний університет».

ORCID: 0000-0001-9030-542X

E-mail: oksana.popova@donntu.edu.ua

Стаття присвячена актуальному питанню у сфері сучасної педагогічної освіти - проблемі розвитку soft skills майбутнього вчителя іноземних мов як консультанта, порадника, вихователя, дослідника, новатора, фасилітатора, того, хто має набір «hard skills» ma «soft skills» для реалізації ефективної професійно-педагогічної діяльності. Передбачається, щзо медіативна компетентність є складовою системи soft skills майбутніх учителів іноземної мови, оскільки медіація забезпечує мовну взаємодію між двома або більше співрозмовниками, коли пряме спілкування між ними неможливе через певні обставини. Метою статті є розроблення 
комплексу вправ для розвитку медіативної компетентності як складової soft skills майбутніх учителів іноземних мов. Для досягнення мети були використані такі теоретичні методи дослідження: аналіз та узагальнення наукової літератури для виявлення ступеня розробленості проблеми дослідження; систематизачія теоретичних положень з метою проєктування комплексу вправ для розвитку медіативної компетентності учнів. Були обрані та описані такі групи вправ для створення комплексу завдань: некомунікативні аналітичні, рецептивні, частково комунікативні медіативні та суто комунікативні. Надані приклади для кожного типу вправ, як-от: відповідність та заповнення прогалин (некомунікативні); виявлення лексичних одиниць, читання текстів з розумінням загальної та детальної інформації (рецептивні); переклад, дубляж, переказ, текстуалізачія інтенцій (частково комунікативні); рольова гра (суто комунікативні). Зроблено висновок, щчо медіативна компетентність майбутніх учителів іноземної мови набувається шляхом інтеграції всіх видів тренувальних вправ. Пропонується спрямувати подальші дослідження на розроблення спеціальних діагностичних засобів для вимірювання рівня soft skills вчителя іноземної мови.

Ключові слова: професійна компетентність; soft skills; медіативна компетентність; медіативна діяльність; професійна підготовка; учитель іноземної мови; студент; вправа.

The system of higher pedagogical education of Ukraine is undergoing essential changes, in particular, it is reforming in the field of teacher training. There is an active search for innovative educational models; a renewed image of a teacher is being formed as a consultant, advisor, tutor, researcher, innovator, facilitator, the one who has a set of "hard skills" and "soft skills" to implement beneficial professional and pedagogical activities. The new Ukrainian school needs teachers who are able not only to master modern methods of teaching and educating students quickly but also to adjust them to the needs of the educational environment, to create and implement their own teaching aids, to organize the learning process on the basis of personality-oriented, competence and activity approaches.

The problem of "hard skills" and "soft skills" has been studied by O. Abashkina, E. Haiduchenko, V. Davydova, N. Zhadko, H. Ivonina, S. Nakhod [9], O. Sosnitska, L. Familyarska [11], J. James Heckman, Tim D. Kautz [14] and others. In particular, L. Koval [5] classifies "soft skills" into individual, communicative, managerial and studies the possibility for students to develop them; N. Dluhunovych [3] considers the problem of developing "soft skills" in the system of future programmers' training. The issue of developing "soft skills" in the process of future teachers' professional training is covered in the works of O. Biljakowska [12], O. Kazachiner [4], L. Sebalo [10].

K. Koval gives the following classification of "soft skills": individual qualities (ability to make decisions and solve problems, clearly set and formulate goals, positive thinking and optimism, customer orientation and end result); communication qualities (ability to clearly express opinions, ability to interact with different types of people, structure and moderate meetings, respond reasonably, clearly, timely and politely, prepare and make quality presentations, take into account cultural and international characteristics); managerial qualities (be a team-player, unite and motivate the team, train and develop team members, anticipate and prevent risks, clearly plan and manage time) [5, p. 165]. In addition, according to L. Familiarska "soft skills" is a sociological term that characterizes the list of personal traits that are in some way related to effective interaction in the process of professional activity: the ability to persuade, make contact with people, interpersonal communication, negotiation, teamwork, personal development, erudition, creativity, interaction, high level of selforganization, etc. [11, p. 43].

At the same time, the problem of soft skills components of future foreign language 
teachers is insufficiently studied, namely the formation of their mediative competence, which is interpreted as mediation that provides language interaction between two or more communicators when direct communication between them is impossible due to certain circumstances [13]. Thus, all the above mentioned determines the relevance of the study.

The article aims at designing a set of exercises for developing the mediative competence as a component of future English teachers' soft skills.

According to the "Common European Framework of Reference for Languages" approach, mediation is one of four main modes of language use, along with reception, production and interaction. Mediation involves not only reception and production, but also a certain "mediation skill" that creates a connection between the receptive and productive aspects of communication [13].

According to R. Ardovska [1], mediation activity as a part of human speech activity is based on a communicative process aimed at transmitting information orally or in writing in a foreign language to a person who does not understand this language. When transmitting information in a foreign language, the mediator performs decoding of information, its understanding and verbalization, i.e. translation into a communicative form aimed at the recipient.

There are two types of mediation: interactive mediation (consecutive interpreting, intention textualization, mediation during negotiations) and non-interactive mediation (translation, gisting, summarizing, abstracting, reviewing) [6]. While developing the mediative competence as a part of soft skills structure of future English language teachers, a special set of exercises has been designed with the focus on the following forms of mediation:

1. intention textualization, which means that the mediator's task is not to translate the text, but to verbalize communicative tasks, such as "Ask...", "Find out...", “Tell...", etc. $[7$, p. 8$]$;

2. written translation or oral interpretation of a text;

3. summarizing of the main content of the text (written or oral);

4. abstracting, i.e. presenting key information of the text (written or oral).

The set of exercises is specially systematized in such a way that their quantity, quality, sequence and ratio of species and subspecies provide the optimal effect in the process of developing the mediative competence at each stage of their development $[8, \mathrm{p} .75]$. The sequence of exercises in the complex is determined by the principles of systematization, situational and thematic organization of learning material, as well as the concept of feasibility. An example of it is a set of exercises structured in the order of complexity of the task and its lexical content. With the benefit of a detailed analysis of exercise types by I. Berteneva [2], a set of exercises has been designed to develop the mediative competence of students in Foreign Languages Teaching. It includes non-communicative, partially communicative and purely communicative exercises.

Thus, the set of exercises for developing the mediative competence of future English teachers includes the following series:

1. non-communicative exercises (analytical);

2. receptive exercises;

3. partially communicative (mediative);

4. communicative exercises (interactive).

The content of the exercises is based on the material of the course "Upstream B2" and 
authentic texts from the websites: http://www.bbc.com/news, https://learnenglish. britishcouncil.org/, https://www.youtube.com.

Non-communicative analytical exercises are focused on the perception of vocabulary through the visual channel, the disclosure of meaning, differentiation at the level of words, phrases, and sentences. They include the following:

1) identifying, differentiating and correlating lexical and terminological units in target language (TL) and source language (SL), for example:

Match the English and Ukrainian equivalents:

\begin{tabular}{|c|c|}
\hline residential area & на околиці \\
\hline centrally located & розташований у центрі \\
\hline in the suburbs & житловий район \\
\hline on the outskirts & у передмісті \\
\hline
\end{tabular}

2) gap-filling based on the techniques of completion / addition, for example:

Fill in the blanks in the text using the words and phrases from the box.

Clock nine-to-five $\quad$ frustrating $\quad$ commute performance

"I work in a fairly traditional office environment doing a typical job. I like my job, but it's annoying that my to work takes an hour and a half each way and most of my work could really be done online from home. But my boss doesn't seem to trust that we will get any work done if left to our own devices, and everyone in the company has to in and out every day. It's that they feel the need to monitor what we do so closely instead of judging us based on our task , like most companies do these days" (https://learnenglish.britishcouncil.org/skills/reading/upperintermediate-b2/work-life-balance).

Receptive exercises are aimed at vocabulary perception, awareness of the content of the text through visual or auditory channels:

1) identifying lexical units, for example:

Watch the video clip on Galapagos islands (https://www.youtube.com/watch? $v=5 g$ iu67eKSA), and write down the words and phrases referring to the topic "Natural habitat".

2) reading/listening for gist (skimming). Students read a text quickly, skim it or listen to audio to get a general idea of it, for example:

Read the article "A dream come true" and choose the best summary.

3) reading/listening for specific information (scanning). Students scan a text or listen to audio to find out certain information: dates, numbers, names, etc., for example:

Listen to the speakers and underline the problems they had while on holidays.

Partially communicative mediative exercises presuppose repeating lexical units and establishing semantic connections between them in order to form automated skills of their usage and to prepare students for real communication [2]:

1. translating which helps to assimilate and activate the lexical units, for example:

Translate the sentences from English into Ukrainian.

1. Fossil fuels will retain their leading role in primary energy production, but in 2035 their share will be reduced to 74 percent.

2. The peaceful use of nuclear energy is currently being revived as states seek new 
ways to produce energy.

3. A wind farm is currently being set up on the site, which will be the first largescale renewable energy project in the Falkland Islands.

Translate the sentences from Ukrainian into English.

1. За кілька кроків від готелю розташований один з найбільш фешенебельних районів, Грінвіч Вілладж.

2. У готелі $\epsilon$ чудово обладнаний тренажерний зал, який гості готелю можуть відвідати у будь-який час дня і ночі.

3. У будь-якому куточку цієї маленької країни ви знайдете першокласні ресторани, удостоєні безлічі нагород.

2. dubbing movie scenes from SL into TL, for example:

Watch a movie scene from "Mean Girls" (https://youtu.be/LZ0v9A5iEG4) in English and dub it into your native language.

This task involves not only practicing purely translation skills, but also summarising the essential information, simplifying the language structures, using appropriate language to convey feelings and emotions, etc.

3. summarising an article, audio recording or video clip in TL, for example:

Write a summary of the video clip on London's great historic houses in English (https://www.youtube.com/watch? $v=o$ MtaeizPkFs).

4. textualising intentions, for example:

- Find out the way to the city centre;

- Describe the problem you are having in your house and request for service.

The purpose of purely communicative interactive exercises, or role-plays, is to creatively comprehend the acquired knowledge and apply their skills and abilities in real situations of professional communication. The objectives of the role-playing game as a methodological approach are as follows: 1) to make students acquainted with problem / conflict everyday situations; 2) to develop the ability to understand the essence of the problem and find ways to solve it [2]. During the role-play, students develop such soft skills as initiative, flexibility, time-management, ability to persuade and settle disputes, ability to convey ideas to partners, ability to clearly and concisely argue their own opinion.

For example, to practise expressing sympathy students are suggested to role play the following situations:

- fire in the basement;

- an aunt fell down the stairs;

- not getting the flat you wanted;

- a friend's daughter burnt her hand on the cooker.

In conclusion, we admit that the acquisition of mediative competence of future foreign language teachers is possible by integrating all types of training exercises. Due to this process, students develop their pedagogical, cultural and foreign language communication skills as integrated personality traits of the future teacher, as well as their professional competence, which will further help them to organize a training at a high professional level. In our opinion, the prospect of further research may be the development of high-quality diagnostic tools to measure the level of formation of "soft skills" of a foreign language teacher. 


\section{СПИСОК ВИКОРИСТАНИХ ДЖЕРЕЛ}

1. Ардовская Р. Сущность понятий «медиативная деятельность» и «медиативная компетентность». 2009. URL: https://docplayer.com/40551886-Obrazovanie-sushchnost-ponyatiy-mediativnaya-deyatelnosti-mediativnaya-kompetentnost.html (дата звернення: 3.08.2021).

2. Бартенева И. К вопросу о классификации упражнений в методической литературе. Альманах современной науки и образования. Тамбов: Грамота, 2010. № 2(33): в 2-х ч. Ч. II. С. 19-22.

3. Длугунович H. Soft skills як необхідна складова підготовки IT-фахівців. Вісник Хмельницького національного університету. 2014. № 6(219). С. 239-242.

4. Казачінер O. "Hard skills" та "soft skills" інклюзивно компетентного вчителя іноземної мови. 2019. URL: http://www.innovpedagogy.od.ua/archives/2019/10/part_1/35.pdf (дата звернення: 15.08.2021).

5. Коваль К. Розвиток "soft skills" у студентів - один із важливих чинників працевлаштування. Вісник Вінницького політехнічного інституту. 2015. № 2. С. 162-167.

6. Колесников А. Формирование медиативной компетенции при обучении иностранным языкам в школе. Вестник Рязанского государственного университета им. С. А. Есенина. 2012. № 34. URL: http://cyberleninka.ru/article/n/formirovanie-mediativnoy-kompetentsii-pri-obuchenii-inostrannymyazykam-v-shkole (дата звернення: 20.08.2021).

7. Латышев Л. Технология перевода. М.: Академия, 2005. 320 с.

8. Методика навчання іноземних мов у середніх навчальних закладах: підручник / під керівн. С. Ю. Ніколаєвої. К.: Ленвіт, 2002. 328 с.

9. Наход C. Значущість “soft skills” для професійного становлення майбутніх фахівців соціономічних професій. Науковий часопис національного педагогічного університету імені М. П. Драгоманова. Серія 5. Вип. 63. 2018. С. 131-135.

10. Себало Л. Soft skills - необхідна складова успішної підготовки майбутнього вчителя початкової школи. 2021. URL: https://ojs.ukrlogos.in.ua/index.php/conferences/article/view/11104/10462 (дата звернення: 20.08.2021).

11. Фамілярська Л. Особливості розвитку сучасного педагога в системі післядипломної освіти. Science Rise: Pedagogical Education. 2014. № 6(14). C. 43-45.

12. Biljakowska O. "Soft skills" як необхідна складова якісної професійної підготовки майбутнього вчителя Rocznik Polsko-Ukraiński. Uniwersytet humanistyczno-przyrodniczy im. Jana Długosza w Częstochowie. 2018. T. XX. S. 175-185. URL: http://212.87.236.17:8080/Content/5918/14_Biljakowska_ Rocznik_20.pdf (дата звернення: 18.08.2021).

13. Common European Framework of Reference for Languages: Learning, teaching, assessment. Council of Europe. 2001. URL: https://rm.coe.int/16802fc1bf (дата звернення: 18.08.2021).

14. Heckman J. J., Kautz T. D. Hard Evidence on Soft Skills. Working Paper 18121; National Bureau of Economic Research. June 2012. URL: http://www.nber.org/papers/w18121 (дата звернення: 10.08.2021).

\section{REFERENCES}

1. Ardovskaya, R. (2009). Sushhnost` ponjatij "mediativnaya deyatel`nost”" i "mediativnaya kompetentnost". URL: https://docplayer.com/40551886-Obrazovanie-sushchnost-ponyatiy-mediativnaya-deyatelnost-imediativnaya-kompetentnost.html [in Russian].

2. Barteneva, I. (2010). K voprosu o klassifikacii uprazhnenij v metodicheskoj literature. Al 'manah sovremennoj nauki i obrazovaniya - Almanac of modern science and education, 2(33), part II, 19-22 [in Russian].

3. Dluhunovych, N. (2014). Soft skills yak neobkhidna skladova pidhotovky IT-fakhivtsiv. Visnyk Khmelnytskoho natsionalnoho universytetu - Gazette of Khmelnytskyi National University, 6(219), 239-242 [in Ukrainian].

4. Kazachiner, O. (2019). "Hard skills" ta "soft skills" inkliuzyvno kompetentnoho vchytelia inozemnoi movy. URL: http://www.innovpedagogy.od.ua/archives/2019/10/part_1/35.pdf [in Ukrainian].

5. Koval, K. (2015). Rozvytok "soft skills" u studentiv - odyn iz vazhlyvykh chynnykiv pratsevlashtuvannia. Visnyk Vinnytskoho politekhnichnoho instytutu - Gazette of Vinnytsia politechnic institute, 2, 16-167 [in Ukrainian].

6. Kolesnikov, A. (2012). Formirovanie mediativnoj kompetencii pri obuchenii inostrannym yazykam v shkole. Vestnik Rjazanskogo gosudarstvennogo universiteta im. S. A. Esenina - Gazette of Ryazan State University named for S. A. Yesenin, 34. URL: http://cyberleninka.ru/article/n/formirovanie-mediativnoy- 
kompetentsii-pri-obuchenii-inostrannym-yazykam-v-shkole [in Russian].

7. Latyshev, L. (2005). Tehnologiya perevoda. M.: Akademiya [in Russian].

8. Metodyka navchannia inozemnykh mov u serednikh navchalnykh zakladakh. (2002). K.: Lenvit [in Ukrainian].

9. Nakhod, S. (2018). Znachushchist "soft skills" dlia profesiinoho stanovlennia maibutnikh fakhivtsiv sotsionomichnykh profesii. Naukovyi chasopys natsionalnoho pedahohichnoho universytetu imeni M. P. Drahomanova - Scientific journal of the National Pedagogical Dragomanov University, ser. 5, issue 63, 131-135 [in Ukrainian].

10. Sebalo, L. (2021). Soft skills - neobkhidna skladova uspishnoi pidhotovky maibutnoho vchytelia pochatkovoi shkoly. URL: https://ojs.ukrlogos.in.ua/index.php/conferences/article/view/11104/10462 [in Ukrainian].

11. Familiarska, L. (2014). Osoblyvosti rozvytku suchasnoho pedahoha v systemi pisliadyplomnoi osvity. Science Rise: Pedagogical Education, 6(14), 43-45 [in Ukrainian].

12. Biljakowska, O. (2018). "Soft skills" yak neobkhidna skladova yakisnoi profesiinoi pidhotovky maibutnoho vchytelia Rocznik Polsko-Ukraiński. Uniwersytet humanistyczno-przyrodniczy im. Jana Dlugosza w Czestochowie - Polish-Ukrainian Yearbook. Jan Dlugosz University in Czestochowa, Vol. XX, 175-185. URL: http://212.87.236.17:8080/Content/5918/14_Biljakowska_Rocznik_20.pdf [in Ukrainian].

13. Common European Framework of Reference for Languages: Learning, teaching, assessment. Council of Europe. (2001). URL: https://rm.coe.int/16802fc1bf

14. Heckman, J. J., Kautz, T. D. (2012). Hard Evidence on Soft Skills. Working Paper 18121; National Bureau of Economic Research. URL: http://www.nber.org/papers/w18121 